\title{
PENERJEMAHAN SUBTITLE DARI BAHASA INGGRIS KE DALAM BAHASA INDONESIA (PENELITIAN ANALISIS ISI PADA SUBTITLE FILM CONTRABAND)
}

\author{
Ziyaul Haq \\ Program Studi Pendidikan Bahasa Inggris, Fakultas Bahasa dan Seni \\ Universitas Indraprasta PGRI. \\ yaul_elite@yahoo.com
}

\begin{abstract}
Abstrak
Penelitian ini bertujuan untuk meneliti strategi penerjemahan pada subtitle film ContraBand. Objek penelitian itu sendiri adalah subtitle film ContraBand yang berbahasa Inggris dan diterjemahkan ke dalam bahasa Indonesia. Penelitian ini menggunakan teknik analisis isi. Temuan penelitian ini berupa kesepadanan di antaar BSu dan BSa, sebelas strategi penerjemahan dan beberapa penyimpangan dalam penerjemahan. Strategi literal merupakan strategi yang paling sering digunakan sebanyak $33 \%$ dari keseluruhan data dan strategi peminjaman merupakan tingkat penggunaan paling rendah sebanyak $0.08 \%$ dari keseluruhan data. Adapun beberapa strategi lainnya yang gunakan adalah compensation, paraphrase, word to word, borrowing, calque, free translation, addition, shift translation, omission, dan compression translation, sedangkan jenis kesepadanan yang ditemukan adalah (1) kesepadanan di tingkat kata;(2) kesepadanan di atas kata; dan (3) kesepadanan gramatika.
\end{abstract}

Kata Kunci: strategi penerjemahan, kesepadanan, penyimpangan dalam penerjemahan, subtitle.

\begin{abstract}
This research is aimed at identifying the translation strategies of the subtitle in the movie ContraBand. Object of this research is the subtitle on the movie ContraBand which is in English and translated into Indonesian in the form of subtitling. This research is a qualitative study using content analysis techniques. The finding of this research as follows, equivalences between SL (source language) and TL (target language), eleven translation strategies, and some translation errors in TL. The majority of translation strategies used on the subtitle is literal translation (33\% of the total data) and the lowest range of strategy used in subtitle translation is borrowing strategy (0.08\%). Then, the other strategies used on this subtitle translation are compensation, paraphrase, word to word, borrowing, calque, free translation, addition, shift translation, omission, and compression translation. Meanwhile, the kinds of equivalence are (1) equivalence at words level;(2) equivalence above words level; and (3) grammatical equivalence.
\end{abstract}

Keywords: translation strategy, equivalence, translation error, subtitle.

\section{PENDAHULUAN}

Saat ini, beberapa negara dapat menjalin komunikasi tanpa batas melalui proses penerjemahan. Penerjemahan itu sendiri bertujuan untuk saling tukar-menukar informasi dengan satu sama lain di setiap negara. Akan tetapi, di dalam proses penerjemahan pada dua bahasa yang berbeda dan dengan latar belakang budaya yang berbeda, Benny Hoedoro Hoed (2006:82) berpendapat bahwa "hal yang sering menjadi kendala dalam penerjemahan adalah adat bahasa (usage) dan gaya bahasa, yang merupakan bagian dari kebudayaan."

Moentaha (2008: 9) mengutip G.jager, menyatakan bahwa proses penerjemahan adalah transformasi teks 
dari satu bahasa ke bahasa lain tanpa mengubah isi teks asli. Dengan demikian, ketika suatu bahasa (BSa) ingin mentransformasikan teks bahasa lain $(\mathrm{BSu})$, maka pesan yang terdapat di dalam bahasa sumbernya harus dipertahankan dan tidak boleh hilang di dalam bahasa sasarannya. Saat ini, dunia penerjemahan film sudah sangat dikenal dan hasilnya banyak dinikmati oleh penikmat film. Dalam penerjemahan film, terdapat dua jenis kegiatan penerjemahan, yaitu Dubbing/ sulih suara dan Subtitling. Khusus pada subtitling, tantangan dalam penerjemahan film ini adalah keterbatasan waktu yang ditentukan dan jumlah karakter yang ditentukan untuk menampilkan tulisan/ subtitle di dalam layar.

Di Indonesia, film-film luar negeri biasanya lebih banyak dinikmati oleh masyarakat Indonesia, khususnya yang berasal dari Hollywood. Akan tetapi, terdapat kendala yang dihadapi oleh penikmat film Hollywood. Kendala terbesar yang dihadapi para penonton tentu saja adalah begitu banyak ragam istilah, slang, idiom, dan istilah budaya yang digunakan di setiap film Hollywood. Film Contra Band merupakan contoh kasus dalam penerjemahan subittle. Film ini berasal dari Negara Amerika Serikat yang berlatar belakang budaya barat dengan menggunakan bahasa inggris sebagai bahasa pengantar atau bahasa sumbernya. Dalam film ini, terdapat banyak istilah-istilah khusus dan beberapa kata yang sama tapi memiliki makna yang berbeda dalam penerjemahannya sesuai dengan konteks yang ada di dalam filmnya.

Berdasarkan latar belakang yang dikemukakan di atas, dapat dirumuskan masalah penelitian sebagai sebagai berikut: "Bagaimanakah penerjemahan subititle film Contra Band dari berbahasa Inggris ke dalam bahasa Indonesia mencapai kesepadanan?"

\section{KAJIAN PUSTAKA Kesepadanan dalam Penerjemahan}

Dalam penerjemahan, seorang penerjemah dituntut untuk mendapatkan kata-kata yang sepadan sehingga terjemahan yang dihasilkan menjadi akurat. Dalam hal kesepadanan dalam penerjemahan, Mona Baker (1992: 26106) mengemukakan beberapa konsep kesepadanan, yaitu (1) kesepadanan di tingkat kata; (2) kesepadanan di atas kata; (3) kesepadanan gramatikal; (4) kesepadanan teks; serta (5) kesepadanan pragmatik.

\section{Strategi Penerjemahan}

Dalam menerjemahankan sebuah teks, Newmark (1988: 45-48) mengusulkan beberapa jenis strategi penerjemahan, yaitu: (1) transference; (2) naturalisasi; (3) cultural equivalent; (4) functional equivalent; (5) descriptive equivalent; (6) synonymy; (7) shift atau transposisi; (8) modulation; (9) compensation; (10) componential analysis;(11) parafrasa. Sebagai tambahan dari jenis strategi penerjemahan, terdapat pula strategi yang dikemukakan oleh Moentaha: (1) terjemahan harfiah; (2). subtitusi; (3) terjemahan bebas. (4). Penggantian; meliputi: penggantian kelas kata; penggantian bagian-bagian kalimat; penggantian leksikal; terjemahan antonym; penambahan; penghilangan; kompresi; derivasi sintaksis; penerjemahan deskriptif amplikasi; eksplikasi/implikasi.

\section{Penyimpangan dalam Penerjemahan}

Menurut ahli penerjemah, Peter Newmark (1981: 7-8), bahwa penyimpangan di dalam penerjemahan dapat terjadi ketika: (1) pergeseran kalimat dalam penerjemahan kerap menimbulkan keganjilan semantik karena adanya penerjemahan leksikal 
dengan adanya perubahan susunan kata; (2) umumnya ada kata-kata atau frasa atau kalimat yang tidak diterjemahkan; (3) penerjemah menggunakan bahasa individu dibandingkan bahasa sosial yang lazim digunakan di dalam masyarakat; (4) perubahan sudut pandang yang berbeda dengan bahasa sumber; (5) banyaknya kesalahan gramatikal dan leksikal. Selanjutnya, Sager mengusulkan klasifikasi jenis penyimpangan dalam terjemahan, yaitu adanya pembalikan makna, penghilangan, penambahan, kelainan/deviasi, dan Modifikasi makna.

\section{Subtitle Film}

Pada 1927, era baru perfilman pun dimulai walaupun pada tahun 1930 muncul silent movies. Pada tahun tersebut para penonton sinema menonton aktor yang menggunakan verbal komunikasi lewat layar. Meskipun tak dapat didengar, elemen bahasa pada film tersebut menambahkan penggunaan subtitle yang berselang yang membantu menjelaskan dialog dan plot cerita, sehingga pada masa ini disebut sebagai plopor munculnya subtitling.

Dalam penerjemahan subtitle, penerjemah harus memahami dimensidimensi linguistik dalam proses penerjemahan subtitle. Dimensi itu meliputi; ringkasan dan kejelasan, subtitling dua baris, penghilangan, tanda baca, perbedaan struktural, dan swearwords. Selanjutnya, yang terakhir, beberapa kata diekspresikan pada proses subtitling. Dari kelima dimensi linguistik untuk penerjemahan subtitle ini, penerjemah terbantu dan mudah melakukan penerjemahan subtitle sesuai dengan pertimbangan-pertimbangan linguistiknya.

\section{METODOLOGI PENELITIAN}

Dalam penelitian ini, peneliti memilih metode analisis isi yang bersifat deskriptif. Adapun tujuan penelitian ini adalah untuk meneliti strategi penerjemahan pada subtitle film ContraBand.

Penelitian yang bersifat deskriptif ini menganalisis isi data yang ditemukan. Adapun penelitian ini dilakukan di Jakarta. Kemudian penelitian ini berlangsung sejak Januari 2013 hingga Maret 2013. Dalam penelitian ini, peneliti akan memaparkan strategi-strategi yang digunakan oleh penerjemah dalam proses penerjemahan subtitle film Contra Band. Dalam penelitian ini, peneliti akan menghimpun seluruh data (subtitle) dan mendeskripsikan setiap unsur yang akan dianalisa. Sehingga penelitian ini merupakan bentuk kajian teks atau analisis isi. Dalam penelitian ini, peneliti menggunakan beberapa sumber kepustakaan dan observasi.

Data penelitian ini meliputi kata, frase, dan kalimat yang diperoleh dari terjemahan subtitle dalam film Contra Band. Data yang berbentuk kata-kata dan kalimat-kalimat dikumpulkan. Kemudian, Peneliti mengelompokkan seluruh subtitle yang ada dalam film tersebut.

Dalam pengelompokan data, peneliti memasukkan data yang diseleksi sesuai dengan jenisnya masing-masing ke dalam tabel-tabel. Dalam tabel itu akan dimasukkan subtitle-subtitle film Contra Band, hasil terjemahan subtitlesubtitle yang berbahasa Indonesia, dan subtitle-subtitle yang berbahasa sumber, bahasa Inggris.

\section{HASIL DAN PEMBAHASAN}

\section{Kesepadanan dalam Penerjemahan Subtitle Film Contraband}

Berdasarkan data subtitle yang diperoleh, dan berlandaskan konsep 
kesepadanan yang dikemukakan oleh Baker, kesepadanan di tingkat kata, di atas kata, dan gramatika di antara BSu dan BSa dapat ditemukan di dalam subtitle film ContraBand. Berikut adalah contoh pembahasan subtitle dan kesepadanan di antara BSu dan BSanya.

TSu: Walter,wake up, customs.

TSa: walter, bangunlah ada polisi (00:02:21)

Seperti yang terlihat TSu di atas, frasa verba wake up secara alami memiliki padanan kata di bahasa Indonesia (BSa) yaitu dalam bentuk kata tunggal "bangun", dan partikel lah pada TSa di atas dalam bahasa digunakan pada kalimat imperatif sebagai penghalus verba "bangun" di dalam kalimat imperatifnya. Sedangkan kata customs dipadankan dengan kata di BSa-nya, yaitu "polisi".

Jika melihat arti dasar kata customs itu sendiri dalam bahasa Indonesia, maka artinya adalah "cukai, bea cukai, atau pabean" atau "lembaga yang menangani kegiatan impor barang dari luar". Akan tetapi, penerjemah menangkap makna kata tersebut tidak hanya bermakna "bea cukai/ pabean", akan tetapi dengan mengacu pada konteks film, kata tersebut bermakna "polisi beacukai", yaitu polisi yang bertugas memeriksa dan mencegah barang-barang selundupan. Hal ini juga didukung dengan adanya frasa di dalam bahasa Inggris, customs police/ customs officer (polisi pabean) yang sering digunakan. Dalam hal kesepadanan di tingkat kata seperti pada kasus penerjemahan di atas, Baker berpendapat bahwa tidak terdapat korespondensi satu lawan satu antara kata dari segi ejaan/bentuk dengan makna di dalam masing-masing bahasa yang berbeda. Misalnya, pada kata tunggal customs di atas memiliki padanan kata di BSa-nya dalam bentuk frasa, yaitu "petugas/ polisi beacukai".

Dalam hal masalah kesepadanan di tingkat kata ini, Baker juga mengemukakan bahwa salah satu strategi yang dapat digunakan oleh penerjemah dalam memadankan kata $\mathrm{BSu}$ dengan $\mathrm{BSa}$ adalah penerjemahan dengan kata yang lebih umum (superordinate). Menurutnya, penerjemahan ini merupakan strategi yang paling lazim ketika tidak terdapat kata yang sepadan, khususnya di dalam wilayah makna proposisional. Sejalan dengan apa yang diuraikan oleh Baker, di dalam penerjemahan subtitle film ini, penerjemah lebih memilih menggunakan kata tunggal "polisi" yang sifatnya lebih umum (general word/ hipernim) daripada frasa kata "polisi beacukai" yang sifat khusus (hiponim).

Selain dari strategi yang menggunakan kata yang lebih umum, terdapat pula strategi penerjemahan yang dikemukakan Baker, yaitu penerjemahan dengan penghilangan yang dapat dilakukan ketika memadankan kata BSu dengan BSa-nya. Pada kasus penerjemahan subtitle di atas, kita dapat melihat, penerjemah subtitlei film tersebut terlihat seperti menghilangkan kata "bea cukai" dari bentuk frasa "polisi beacukai" (customs) walaupun dari pengilangan ini juga memunculkan kesan bahwa penerjemah lebih memilih kata "polisi" yang sifatnya lebih umum daripada kata "polisi beacukai". Jika penerjemahan di atas dipandang menggunakan strategi penghilangan, maka dapat dianggap bahwa penerjemah subtitle film tersebut berharap bahwa pembaca dapat memahami terjemahan tersebut.dengan hanya melihat konteks pada film tersebut.

TSu: Harry up. Come on. $\mathrm{Pu}$ it in the bag

TSa: Cepatlah, ayolah, maksukkan ke dalam tas. (00:02:32) 
Seperti yang terlihat pada TSu dan TSa di atas, kedua-duanya berbentuk kalimat imperatif dan frasa verba hurry up dipadanankan dengan kata "cepatlah", sedangkan frasa come on dipadankan dengan "ayolah". Adapun arti dasar frasa hurry up yaitu, "bergegas, mempercepat, dst" atau suatu ungkapan yang menunjukkan, membutuhkan sesuatu dengan segera dalam keadaan mendesak. Sedangkan frasa come on yang dalam bahasa Indonesia berarti "ayo" adalah ungkapan yang digunakan untuk membuat seseorang melakukan sesuatu segera.

Seperti yang terlihat pada kata hurry up yang berarti "mempercepat" diterjemahkan dengan "cepatlah". Hal ini disebabkan oleh bentuk kalimat TSu-nya adalah kalimat imperatif sehingga kata yang tepat adalah "cepatlah" yang di dalam bahasa Indonesia sendiri bentuk ini juga merupakan kalimat imperatif. Sedangkan kata come on yang berarti "ayo" di dalam TSu dan TSa di atas juga berbentuk kalimat imperatif yang sifat ajakan, yaitu ketika Andy mengajak Walter untuk melarikan diri dari kapal.

Mengenai masalah kesepadanan di atas kata, Baker mengemukakan bahwa frasa verba/idiom dapat saja bersifat menyesatkan, hal ini terjadi karena idiom menawarkan interpretasi makna literal. Dengan demikian, ;penerjemah bisa saja terjebak dengan tiap-tiap unsur kata yang dapat diterjemahkan secara literal. Misalnya, pada frasa verba come on pada TSu di atas, dapat saja penerjemah menerjemahkannya dengan "datang kepada". Begitu juga pada frasa verba hurry up, jika diterjemahkan secara harfiah maka menjadi "buru-buru ke atas". Dengan demikian, penerjemah yang menemukan frasa di dalam $\mathrm{TSu}-$ nya harus mengetahui dan dapat mengidentifikasi bahwa bentuk kata tersebut tidak dapat diterjemahkan secara harfiah akan tetapi mencari padanannya di BSa-nya.

Dalam penerjemahan frasa/ idiom $\mathrm{BSu}$ ke dalam BSa, menurut Baker, penerjemah pasti akan mengalami kesulitan-kesulitan dalam menerjemahkannya. Dalam mencari padanan frasa/idiom, Baker berpendapat bahwa suatu bahasa mungkin mengungkapkan makna kata dengan kata tunggal, sedangkan bahasa yang lain dengan sebuah ungkapan, dan bahsaa yang lainnya lagi menggunakan ungkapan idiom dan seterusnya, dan makna yang disampaikan pun ketigatiganya sama. Misalnya pada frasa verba TSu di atas hurry up dan come on memiliki padanan kata di bahasa Indonesia tidak berbentuk frasa, akan tetapi justru berbentuk kata tunggal, yaitu "berbegas"(hurry up) dan "ayo" (come on).

TSu: He's my best friend, best man at my wedding.

TSa: dia teman terbaikku di pernikahanku.(00:03:54)

Dalam hal yang berkaitan dengan kesepadanan konsep Jender di antara $\mathrm{BSu}$ dan BSa, Baker mengemukakan bahwa bahasa Inggris tidak memiliki kategori gender; kata bahasa Inggris tidak mengalami perubahan bentuk untuk menunjukkan feminisme dan maskulin. Selanjutnya, Jender bahasa Inggris hanya dapat dilihat dari beberapa nomina yang berbeda digunakan untuk mengacu pada kata yang maskulin dan feminism, misalnya pada kata: cow/bull, sow/boar, doe/stag, mare/stallion, ewe/ram. Sebagai tambahan, perbedaan gender dalam wilayah semantik khusus, bahasa Inggris juga memiliki kategori orang, yaitu orang ketiga tunggal antara feminism (she), maskulin (he) dan jamak ketiga tunggaI they yang 
penggunaanya tidak dibedakan. Dengan demikian, seperti yang terlihat pada $\mathrm{TSu}$ dan TSa di atas, pronomina $\mathrm{He}$ jelas menunjukkan pada seseorang yang berjenis kelamin pria. Dengan demikian, ketika seorang penutur bahasa Inggris menyebut kata $\mathrm{He}$ maka orang yang dimaksud dengan mudah diketahui bahwa orang tersebut adalah seorang pria.

Berbeda dengan bahasa Inggris, bahasa Indonesia tidak memiliki spesifikasi pronomina yang menjelaskan tentang wanita/pria yang dimaksudkan. Seperti pada kata "dia”, orang yang berbicara bahasa Indonesia tidak akan dapat mengetahui bahwa orang yang dimaksud itu pria ataukah wanita. Dengan demikian, untuk mengetahui maksud dari pembicaraan yang menggunakan pronominal "dia" dalam bahasa Indonesia harus mengetahui dan memahami konteks pembicaraan bahwa apakah yang dimaksud "dia" itu adalah seorang pria atau wanita.

\section{Strategi Penerjemahan dalam Subtitle Film ContraBand}

TSu: Flight 104 is 500 yard in trail, waiting for your go.

TSa: Helikopter 104 berjarak 500 yard, menunggu perintahmu

Seperti yang terlihat pada TSu dan TSa di atas, ketika penerjemah melihat kata Flight yang diucapkan di dalam film tersebut, penerjemah pun menerjemahkan kata flight dengan kata "helikopter". Strategi penerjemahan yang digunakan ini adalah parafrasa. Sebagaimana yang telah dijelaskan pada bab sebelumnya, dilatari oleh strategi penerjemahan Newmark, bahwa parafrasa digunakan untuk menjelaskan makna dari suatu bagian teks atau karena adanya penghilangan dan implikasi tertentu di bagian kalimat. Sedangkan Moentaha mengemukakan bahwa strategi ini bertujuan untuk mencapai kesamaan/padanan konteks/ situasi. Biasanya, penerjemah menggunakan kata yang berbeda tapi berkaitan untuk menjelaskan apa yang terdapat di dalam TSu ke dalam TSa. Seperti pada kata flight yang diucapkan oleh polisi dalam film tersebut, kata ini sifatnya lebih umum (hipernim) dibandingkan dengan kata "helikopter". Kata filght mencakup seluruh jenis sarana penerbangan sedangkan "helikopter" bagian dari filght yang sifatnya lebih khusus/spesifik (hiponim). Filght yang berarti "penerbangan" dapat saja menimbulkan banyak makna. Flight yang dimaksud bisa saja "sarana penerbangan/ pesawat terbang", ataukah "kegiatan penerbangan". Akan tetapi, dengan mengacu pada konteks film, yang ditampilkan pada adegan film tersebut, penerjemah pun memilih kata "helikopter" sebagai terjemahannya karena sarana penerbangan yang digunakan dalam film adalah helikopter.

Kata go yang fungsinya sebagai nomina pada TSu di atas juga diterjemahkan dengan menggunakan strategi parafrasa. Berdasarkan kamus Oxford, kata go yang berfungsi sebagai nomina berarti "usaha, percobaan, tindakan, serangan," dst. Dengan mengacu pada konteks film, polisi memang sedang melakukan "percobaan, tindakan, serangan" terhadap kapal yang ditumpangi Andy dan Walter. Akan tetapi jika ucapan polisi terhadap atasannya yang berbunyi waiting for your go diterjemahkan secara literal, maka akan menjadi "menunggu tindakanmu/seranganmu". Melihat ungkapan ini, penerjemah pun menggunakan stratergi parafrasa dengan menerjemahkan go (yang berarti tindakan/ serangan, dst.) dengan kata "perintah". Hal ini dilakukan oleh penerjemah berdasarkan konteks dalam film tersebut bahwa "tindakan/ 
serangan" yang dilakukan oleh polisi tersebut bersifat "perintah" dan hanya dapat dilakukan oleh polisi tersebut segera jika kepala polisi beacukai tersebut memerintahkan untuk segera menyerang kapal tersebut.

TSu: Yeah, I remember, too.

TSa: Ya, aku mengingatnya juga. (00:04:04)

Sebagaimana yang dikemukakan oleh Newmark pada bab sebelumnya bahwa di dalam penerjemahan literal, konstruksi gramatikal BSu diubah ke dalam konstruksi yang sama di dalam BSa, tapi kata-kata leksikal diterjemahkan satu per satu dan tidak mengikutsertakan konteks. Seperti yang terlihat pada TSu dan TSa di atas, penerjemah memilih strategi penerjemahan literal disebabkan oleh bangun sintaksis dari kalimat TSu-nya sangat sederhana sehingga tidak ada kesulitan dan masalah untuk menerjemahkannya secara literal.

TSu: So you said King Security put the system in?

TSa: kau bilang king Security yang memasang sistimnya? (00:11:10)

$\mathrm{TSa}$ di atas menggunakan strategi penerjemahan borrowing Itransference (peminjaman). Dalam penerjemahan peminjaman ini, Newmark menjelaskan bahwa penerjemahan ini memidahkan kata $\mathrm{BSu}$ ke dalam tkes BSa. Sedangkan Menurut Vinday dan Darbelnet, penerjemahan ini bertujuan untuk mengatasi kekosongan. Penerjemahan ini digunakan agar memperkenalkan rasa bahasa dari budaya bahasa sumbernya ke dalam terjemahannya. Istilah asing bisa saja digunakan dalam penerjemahan ini. Seperti yang terlihat pada kata king Security di atas, kata tersebut merupakan sebuah nama merek produk sistem keamanan rumah, sehingga penerjemah pun tidak menerjemahkan kata tersebut. Seperti yang dijelaskan sebelumnya bahwa strategi peminjaman digunakan untuk mempertahankan rasa bahasa BSu dan kata-kata yang merupakan sebuah nama-nama tertentu di dalam budaya dan lingkungan $\mathrm{BSu}$ tidak sepatutnya ikut diterjemahkan.

\section{Penyimpangan Penerjemahan dalam Subtitle Film ContraBand}

TSu: Your old man getting jailed freak you out? Huh?

TSa: masuk penjara membuatmu ketakutan kan? (00:05:39)

Terjemahan di atas merupakan salah satu penyimpangan yang terjadi dalam subtitle film ContraBand. Frasa pada TSu di atas, your old man yang berfungsi sebagai subyek kalimat tidak diterjemahkan di TSa-nya. Hal ini menimbulkan perubahan makna di TSanya. Seperti yang terlihat di TSa-nya, kata "masuk penjara" justru berfungsi sebagai subyek kalimat menggantikan your old man yang berfungsi subyek kalimat di Tsu yang tidak diterjemahkan di TSa.

Pada TSa-nya, terlihat bahwa "masuk penjara" (subyek kalimat) membuat Chris takut, atau dengan kata lain Chris takut masuk penjara tanpa sebab yang lain. Sedangkan pada Tsunya, your old man (subyek kalimat) yang dimaksud adalah ayah Chris yang masuk penjara. Karena ayahnya masuk penjara maka Chris pun dianggap takut mengikuti jejak ayahnya. Dengan demikian dapat dilihat bahwa ketakutan Chris dipicu oleh sebab lain, yaitu ayahnya yang masuk penjara.

Penghilangan ini jelas menimbulkan makna yang berbeda atau keutuhan makna TSu-nya berubah di Tsa-nya sehingga menimbulkan penyimpangan penerjemahan di TSa-nya.

\section{Sebab Penyimpangan Penerjemahan dalam Subtitle Film ContraBand}


TSu: Let's go, Rug Doctor.

TSa: ayo pergi, $\underline{\text { Rug Dokter }}$.(00:27:51)

Terjemahan di atas merupakan salah satu penyimpangan yang terjadi dalam subtitle film ContraBand disebabkan oleh kesalahan gramatikal dan leksikal dalam terjemahan. Seperti yang terlihat pada TSu dan TSa di atas, ungkapan tersebut diucapkan oleh kapten kapal kepada Chris setelah mengetahui ternyata Chris menaiki kapalnya. Pada saat itu pula, kapten menurunkan pangkatnya menjadi petugas pembersih karpet kapal. Frasa pada TSu di atas, Rug Doctor. adalah gelar atau panggilan yang ditujukan kepada Chris setelah hanya ditugaskan sebagai tukang bersih-bersih kapal.

Terjemahan pada frasa rug doctor di atas mengalami penyimpangan dalam leksikal. Hal ini dapat dibuktikan jika melihat dari arti kata rug itu sendiri adalah karpet/ permadani dan doctor adalah dokter. Masing-masing dari kedua kata ini memiliki arti dan jika diterjemahkan secara leksikal atau parafrasa dapat dipahami dalam konteks film tersebut. Misalnya, pada kata doctor (dokter) yang lazim nya bertugas untuk "merawat" orang, akan tetapi, dalam rangkaian kata tersebut, kata doctor justru berpasangan dengan kata rug (karpet), sehingga menimbulkan pemahaman bahwa maksud dari frasa tersebut adalah orang yang merawat karpet atau dapat dikatakan sebagai orang yang memperhatikan kebersihan karpet. Arti rug doctor yang jika diterjemahkan dengan "pembersih karpet" juga dikuatkan dengan ungkapan sebelumnya, yaitu ungkapan yang diucapkan kapten kapal kepada Chris yang berbunyi You scrub dirt and stay fuck outta my sight (Kau membersihkan debu dan menjauhlah dariku), kemudian dilanjutkan dengan ungkapan yang diucapkan oleh Chris yang berbunyi Oh, man carpet cleaner.
(Oh astaga. Pembersih karpet). Dengan demikian, penerjemahan yang dilakukan oleh penerjemah dapat dikatakan menyimpang karena terjemahan nya terlihat bukan suatu terjemahan atau bahkan frasa tersebut terlihat tidak diterjemahkan oleh penerjemahnya.

\section{SIMPULAN}

Berdasarkan analisis penerjemahan subtitle film di atas, dapat disimpulkan bahwa kesepadanan terjemahan subtitle dari bahasa Inggris ke dalam bahasa Indonesia dalam film ContraBand dengan menggunakan sudut pandang teori kesepadanan Mona Baker menuntun peneliti menemukan tiga tingkat kesepadanan, yaitu kesepadanan di tingkat kata, kesepadanan di atas kata, dan kesepadanan gramatikal. Adapun sebelas strategi penerjemahan yang digunakan oleh penerjemah adalah parafrasa, kompensasi, literal, kata per kata, penghilangan, kompresi, penambahan, transposisi, bebas, calque, peminjaman. Namun, dari kesebelas strategi tersebut, strategi yang jumlah penggunaannya tertinggi adalah strategi literal yang berjumlah 401 unit subtitle, dilanjutkan dengan strategi strategi penghilangan dengan jumlah 268 unit subtitle, dan strategi yang berada diurutan tertinggi ke tiga adlaah strategi transposisi/shift dengan jumlah 218. Adapun strategi peminjaman hanya dilakukan pada satu unit subtitle saja sehingga termausk dalam jumlah paling sedikit yaitu satu buah unit subtitle.

Dari penelitian ini, terdapat beberapa penyimpangan yang menyebabkan kelainan atau kekauan hasil terjemahan. Dari sudut pandang jenis penyimpangan Sager, ditemukan penyimpangan dari segi pembalikan makna, kelainan/deviasi, dan penghilangan yang mengubah makna. Dari 
jenis penyimpangan yang ditemukan, peneliti juga menemukan sebab-sebab penyimpangan dengan sudut pandang teori penyimpangan Newmark, yaitu adanya kata-kata, frasa, atau kalimat yang tidak diterjemahkan, kesalahan kesepadanan gramatikal dan leksikal, dan adanya perubahan sudut pandang yang berbeda dengan bahasa sumber.

Berdasarkan hasil penelitian, peneliti menyarankan kepada penerjemah subtitle film ContraBand dan para penerjemah lainnya bahwa seorang penerjemah ketika menerjemahkan BSu ke Bsa perlu memperhatikan kesepadanan dari tingkat kata, frasa, dan kalimat antara BSu dan BSa agar hasil terjemahan pada $\mathrm{BSa}$ sesuai dengan makna pesan pada $\mathrm{BSu}$ sehingga terhindar dari segala penyimpangan-penyimpangan dalam penerjemahan. Selanjutnya, untuk menemukan kesepadanan antara kedua Bahasa yang berbeda, penerjemah harus memiliki keterampilan penerjemahan dengan menguasai beberapa strategi penerjemahan.

\section{DAFTAR PUSTAKA}

Bassnet, Susan. TranslationStudies, $3^{\text {rd }}$ ed. (New York: Routledge, 2005).

Hoed, Benny Hoedoro. Penerjemahan dan Kebudayaan (Jakarta: Pustaka Jaya, 2006)

Choliludin, S.Pd., The Technique of Making Idiomatic Translation, (Jakarta: Kesaint Blanc, 2005)

Emzir. Metodologi Penelitian Kualitatif Analisis Data (Jakarta: Rajawali Pers, 2010).

Hatim, Basil dan Jeremy Munday. Translation: An Advanced resource book ( London and New York : Routledge, 2004).

Hatim, Basil, dan Ian Mason. The Translator as Communicator (London \& New York: Routledge, 2005).

Machali, Rohaya. Pedoman bagi Penerjemah (Jakarta: PT.Grasindo, 2000)

Mark, Aronoff and Janie Ress-Miller. The Handbook of Linguistics.

Moentaha, MA, Salihen Ph. D. Bahasa dan Terjemahan, (Jakarta: Kesaint Blanc 2008).

Mona Baker, In Other Words: A Course Book of Translation. London: Routledge, 1992

Newmark, Peter. A Textbook of Translation (Hertfordshire: Prentice Hall International Ltd, 1988).

Newmark, Peter. About Translation (UK: Multilingusl Matters, 1991).

Newmark, Peter. Approach to Translation (Oxford: Pergemon Press, 1981)

Sanchez, Diana. Subtitling method and team-translation in Topics in Audiovisual Translation. Edited by Pilar Orero, Universitat Autonoma de Barcelona, Spain. (Amsterdam/Philadelphia: John Benjamins Publishing Company, 2004).

Sheng-Jie Chen. Linguistic Dimensions of Subtitling. Perspective from Taiwan in Meta: Translator's Journal, vol 49. 2004. 